\title{
POLA KALIMAT BAHASA INDONESIA TULIS PEMBELAJAR BIPA TINGKAT PEMULA ASAL TIONGKOK DI UNIVERSITAS MA CHUNG TAHUN 2018
}

\author{
Yohanna Nirmalasari ${ }^{1}$ \\ ${ }^{1}$ Universitas Ma Chung, yohannanirmalasari@machung.ac.id
}

\begin{abstract}
Abstrak: Pemahaman sebuah bahasa dapat direpresentasikan melalui penggunaan kalimat, baik lisan ataupun tulis. Kalimat adalah hasil buah pikiran yang diwujudkan dalam bentuk gabungan kata dengan kata, frasa dengan frasa, ataupun klausa dengan klausa. Kalimat yang diproduksi oleh penutur asli dengan penutur asing yang belajar bahasa Indonesia tentu berbeda. Perbedaan ini dapat teramati melalui pola fungsi sintaktis yang digunakan dalam memproduksi kalimat yang diujarkan baik lisan maupun tulis. Namun, dalam kalimat lisan tentu seorang penutur akan banyak menggunakan delesi ataupun elipsis. Dengan kata lain, pola sintaktis akan lebih dapat teramati melalui kalimat tulis. Oleh sebab itu, penelitian berkaitan dengan pola kalimat bahasa Indonesia tulis pembelajar BIPA tingkat pemula asal Tiongkok perlu dilakukan. Di dalam penelitian ini, kalimat akan dianalisis berdasarkan analisis struktural tata bahasa Indonesia, yakni berdasarkan fungsi sintaktisnya. Hasil penelitian ini menunjukkan bahwa kalimat yang diproduksi oleh pembelajar dapat dikategorikan menjadi dua, yakni kalimat berklausa dan kalimat tidak berklausa. Kalimat berklausa tersebut merupakan kalimat berklausa sederhana karena hanya terdiri dari satu klausa. Kalimat berklausa ini dapat dipilah menjadi lima pola berdasarkan fungsi sintaktisnya, yakni kalimat yang berpola sintaktis S-P, S-P-O, S-P-Pel, S-P-Ket, dan S-P-O-Ket. Masingmasing pola kalimat tersebut ada yang berterima dan ada yang tidak berterima.
\end{abstract} berklausa

Kata Kunci: pola kalimat, fungsi sintaktis, kalimat berklausa, kalimat tidak PENDAHULUAN

Bahasa dapat dipilah menjadi dua jenis, yakni bahasa pertama dan bahasa kedua. Bahasa pertama adalah bahasa yang dikenal dan dipelajari sejak dari lahir. Muliastuti (2017:12) menyatakan bahwa istilah bahasa pertama merujuk pada bahasa yang pertama diperoleh anak. Biasanya bahasa pertama disebut juga sebagai bahasa asli atau bahasa ibu. Sementara itu, bahasa kedua merupakan bahasa yang diperoleh setelah bahasa pertama. Bahasa kedua ini diperoleh melalui lingkungan pembelajaran. Menurut Tadjudin, Djajasudarma, dan Wahya (1999:17), pemerolehan bahasa kedua merupakan salah satu proses dalam pembelajaran bahasa. Jadi, tidak akan mungkin seseorang dapat memperoleh bahasa tanpa adanya proses pembelajaran bahasa. Apabila orang Indonesia sejak lahir mendengar dan memperoleh bahasa Indonesia sehingga bahasa Indonesia menjadi bahasa sehari-hari untuk bertutur hingga di kemudian hari orang tersebut belajar bahasa Inggris, bahasa Indonesia disebut sebagai bahasa pertama, sedangkan bahasa Inggris disebut sebagai bahasa kedua. Hal ini berlaku pula pada orang asing yang belajar bahasa Indonesia.

Orang asing yang belajar bahasa Indonesia dapat belajar di Indonesia atau di negara asal mereka yang menyediakan program BIPA. Di Indonesia, program BIPA diwadahi oleh lembaga-lembaga atau universitas. BIPA kepanjangan dari Bahasa Indonesia bagi 
Penutur Asing. BIPA menjadi salah satu jembatan untuk mengenalkan bahasa Indonesia pada warga asing secara formal. Suyitno (2004:59) menyatakan bahwa pembelajaran bahasa Indonesia untuk penutur asing termasuk dalam pembelajaran bahasa kedua, yakni mempelajari suatu bahasa setelah pelajar menguasai bahasa pertama atau bahasa ibunya. Maraknya pembelajaran BIPA memicu banyak universitas untuk menyelenggarakan program BIPA. Salah satu universitas yang menyelenggarakan program BIPA di kota Malang adalah Universitas Ma Chung. Program BIPA di Universitas Ma Chung dikhususkan bagi pemelajar yang berasal dari Tiongkok, tetapi tidak menutup kemungkinan dalam pengembangan program BIPA ini akan ada pemelajar asing selain dari negara Tiongkok.

Pemelajar dari Tiongkok yang datang ke Malang dan mengikuti program BIPA ini dapat belajar bahasa Indonesia melalui input dari pembelajaran formal di dalam kelas dan dari lingkungan masyarakat di kota Malang. Materi yang diperoleh pemelajar akan dapat dipraktikkan di luar kelas sehingga ada proses reseptif dan produktif dalam belajar bahasa Indonesia. Hal ini memudahkan untuk menguasai bahasa kedua dengan cepat dan baik.

Hasil belajar bahasa Indonesia melalui program BIPA dapat teramati melalui kalimat yang ditulis oleh pemelajar baik lisan ataupun tulis. Kalimat merupakan salah satu bentuk kegiatan produktif berbahasa. Kalimat yang dilisankan atau ditulis oleh pemelajar mengikuti tata bahasa Indonesia. Menurut Saville dan Troike (2006:162), produksi berbahasa baik lisan ataupun tulis terlebih dahulu memerlukan pengetahuan terkait dengan kata, morfologi, fonologi, sintaksis, dan struktur wacana yang akan dipakai untuk mengombinasikan semua aspek tersebut dalam frasa, klausa, dan unit wacana yang lebih kompleks. Jadi, seseorang tidak akan dapat memproduksi sebuah kalimat apabila tidak ada pemahaman yang terkait dengan unit-unit kecil di dalam kalimat. Kalimat dapat disebut sebagai unit terbesar sebelum wacana atau teks karena kalimat merupakan gabungan dari beberapa kata atau dari beberapa klausa atau frasa.

Kalimat merupakan salah satu aspek yang dapat dijadikan sebagai bukti pengetahuan pemelajar. Kalimat juga dapat merepresentasikan sejauh mana mereka dapat berkomunikasi menggunakan bahasa Indonesia dengan tepat. Sumadi (2009:150) menyatakan bahwa kalimat adalah satuan gramatik yang dibatasi kesenyapan awal dan kesenyapan akhir yang menunjukkan bahwa kalimat itu sudah selesai atau sudah lengkap. Kalimat yang diujarkan secara lisan tentu berbeda dengan kalimat tulis karena ketika memproduksi bahasa lisan, pemelajar akan secara langsung mengucapkan kalimatnya. Sebaliknya, dalam memproduksi kalimat tulis, pemelajar memiliki waktu yang lebih banyak untuk menyusun kalimat sehingga akan tampak semua simpanan berkaitan dengan tata bahasa Indonesia yang sudah diajarkan padanya. Menurut Langacker (1973:59), tulisan merupakan salah satu bentuk fakta dan ide yang dapat dipertanggungjawabkan dan bersifat permanen. Jadi, penguasaan bahasa Indonesia sebagai bahasa kedua akan lebih tampak.

Penguasaan bahasa Indonesia sebagai bahasa kedua yang direpresentasikan melalui kalimat memiliki pola. Hal ini disebabkan adanya perbedaan tata bahasa Indonesia dengan tata bahasa ibu pemelajar, yakni bahasa Tiongkok. Pola ini dapat diamati melalui penggunaan fungsi sintaktis dalam menulis kalimat. Jadi, penelitian ini akan memaparkan 
pola kalimat bahasa Indonesia tulis pemelajar BIPA tingkat pemula asal Tiongkok di Universitas Ma Chung Tahun 2018.

\section{METODE PENELITIAN}

Penelitian ini dilakukan dengan menggunakan jenis penelitian analisis sintaksis dengan pendekatan struktural. Penelitian analisis kajian teks dipilih karena penelitian ini memeriksa secara sistematis pola kalimat yang ditulis oleh pemelajar BIPA pada kuis akhir. Penelitian ini menghasilkan analisis kalimat berdasarkan hadir tidaknya klausa yang digunakan oleh pemelajar.

Sumber data penelitian ini adalah kuis akhir mahasiswa tingkat pemula dalam program pertukaran pelajar di Universitas Ma Chung tahun 2018. Data penelitian ini ialah kalimat tulis mahasiswa. Data diperoleh setelah pembelajaran BIPA usai.

Penelitian ini menggunakan instrumen utama dan instrumen penunjang. Peneliti menjadi instrumen kunci yang berperan sebagai partisipan aktif karena mengumpulkan data secara langsung. Selain itu, peneliti juga menggunakan instrumen penunjang berupa tabel kodifikasi, pedoman analisis data, dan tabel analisis data.

Teknik pengumpulan data penelitian ini dilakukan melalui studi dokumen. Peneliti melakukan perizinan. Selanjutnya, peneliti memindai kalimat yang sudah ditulis oleh pemelajar.

Analisis data dapat dikategorikan menjadi dua, yakni tahapan analisis data umum dan khusus. Secara umum, analisis data dilakukan dengan pereduksian, penyajian data, dan penafsiran data. Secara khusus, analisis data dilakukan berdasarkan fokus penelitian. Pertama, data direduksi berdasarkan kriteria data. Selanjutnya, data dimasukan dalam tabel analisis data yang dipilah menjadi dua, yakni kalimat berklausa dan tidak berklausa. Kemudian, data diberi kode. Kedua, data disajikan secara deskriptif sesuai dengan kategori kalimat berklausa dan tidak berklausa. Kalimat yang berklausa diklasifikasi berdasarkan pola sintaktisnya. Data kalimat yang sudah diklasifikasi dan dikode akan dipaparkan secara deskriptif. Ketiga, data akan diinterpretasi sehingga peneliti dapat menarik simpulan.

Proses keabsahan data dilakukan melalui triangulasi teori. Pada triangulasi ini peneliti mengkaji teori yang berkaitan dengan kalimat sejak awal penelitian hingga tahapan analisis data.

\section{TEMUAN DAN PEMBAHASAN}

Kalimat adalah salah satu wujud produksi berbahasa. Kalimat merupakan susunan dari beberapa kata yang menduduki fungsi sintaktis tertentu. Fungsi sintaktis ini merupakan tataran pertama dan tertinggi yang terdiri dari subjek $(\mathrm{S})$, predikat $(\mathrm{P})$, objek $(\mathrm{O})$, pelengkap (Pel), dan keterangan (Ket). Pada penelitian ini, ada dua jenis kalimat yang dapat ditemukan berdasarkan unsurnya, yakni kalimat berklausa dan kalimat tidak berklausa. Berikut adalah paparannya. 


\section{Kalimat Berklausa}

Kalimat berklausa adalah kalimat yang terdiri atas satuan gramatik berupa klausa (Sumadi, 2009:163). Klausa disebut pula sebagai inti kalimat, sehingga ciri dan jumlah klausa dapat digunakan pula sebagai penentu jenis kalimat. Jenis kalimat yang ditemukan dalam penelitian ini merupakan kalimat sederhana karena hanya memiliki satu klausa. Kalimat berklausa ini dapat dikategorikan berdasarkan pola fungsi sintaktisnya, yakni subjekpredikat (S-P), slubjek-predikat-objek (S-P-O), subjek-predikat-pelengkap (S-P-Pel), subjekpredikat-keterangan (S-P-Ket), dan subjek-predikat-objek-keterangan (S-P-O-Ket). Fungsifungsi sintaksis ini ditempati oleh frasa. Verhaar (2010:162) menyatakan bahwa di dalam klausa ada konstituen yang merupakan satuan gramatikal berupa kata atau frasa yang menduduki fungsi tertentu. Berikut adalah paparannya

Pertama, kalimat berpola fungsi sintaktis $\boldsymbol{S}$-P. Kalimat berpola fungsi sintaktis S-P hanya ditemukan pada kalimat ekuatif dan kalimat statif. Kalimat ekuatif merupakan kalimat yang fungsi predikatnya diisi oleh nomina. Sementara itu, kalimat statif merupakan kalimat yang fungsi predikatnya diisi oleh adjektiva. Berikut adalah paparan data dan pembahasannya.

${ }^{1}$ Nama saya Victoria.(t//a/VI)

Kutipan di atas merupakan kalimat yang terdiri dari fungsi sintaksis S dan P. Kalimat tersebut terdiri dari satu klausa, yaitu nama saya Victoria. Klausa ini terdiri dari dua frasa yang masing-masing frasanya menduduki struktur fungsi S dan P. Hal ini sesuai degan pernyataan yang dikemukakan oleh Sumadi (2009:18) bahwa jumlah frasa dalam sebuah kalimat bergantung pada jumlah fungsi sintaktis yang terdapat dalam kalimat. Apabila di dalam kalimat terdapat dua frasa, kalimat tersebut hanya memiliki dua fungsi sintaktis seperti pada kalimat tersebut, pun sebaliknya. Kata yang menduduki struktur fungsi $\mathrm{S}$ adalah kata nama saya karena kata ini merupakan FN (Frasa Nomina) yang terbentuk dari N + Pron $\left(\right.$ nama $\left._{n m n}+{ }_{\text {saya }} a_{\text {rnm}}\right)$. Walaupun terdiri dari nomina dengan pronomina, frasa tersebut dikategorikan dalam FN karena yang menjadi konstituen induk adalah nama dan yang menjadi konstituen bawahan adalah saya. Sementara itu, kata yang menduduki fungsi $\mathrm{P}$

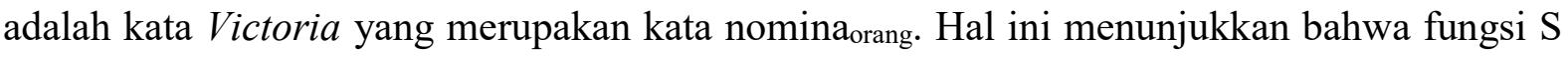
merujuk pada fungsi $\mathrm{P}$, dan sebaliknya. Kalimat seperti inilah yang disebut sebagai kalimat ekuatif. Menurut Sumadi (2009:143), kalimat ekuatif ialah klausa yang fungtor S-nya mempunyai rujukan sama dengan P. Selain itu, FN tersebut terdiri dari konstruksi semantik $\mathrm{N}$ pertama merupakan pokok, sedangkan $\mathrm{N}$ kedua adalah penjelas macam. Hal ini sesuai dengan teori yang dikemukakan oleh Samsuri (1982:96) bahwa FN yang terdiri dari N+N dan $\mathrm{N}$ kedua adalah nama, maka nomina kedua tersebut merupakan penjelas macam karena saya merupakan pronomina persona pertama tunggal. Selain contoh tersebut, berikut adalah contoh kalimat berstruktur S-P dengan berpredikat adjektival.

${ }^{2}$ Pakaian kita merah.(t2/a/A3)

Kutipan kalimat di atas memiliki satu klausa yang terdiri dari fungsi S dan P. Kalimat tersebut terbentuk dari FN+FA yang dapat dijabarkan menjadi $(\mathrm{N}+\mathrm{Pr})+(\mathrm{A})$ \{pakaian $_{\mathrm{nmn}}+$

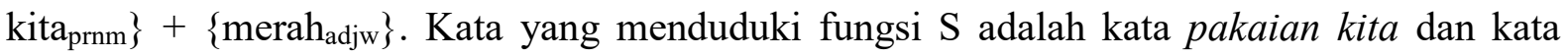
yang menduduki fungsi $\mathrm{P}$ adalah kata merah. Secara struktur tersebut dapat dinyatakan

Volume 2 No. 1.2018 | 44 
bahwa kalimat tersebut merupakan kalimat statif karena berpredikat adjektiva. Menurut Alwi, dkk (2010:357), kalimat yang predikatnya adjektiva sering dinamakan kalimat statif. Kalimat statif dapat diketahui kebenarannya dengan menambahkan kata pengingkar tidak. Namun, jika ditambahkan pada kalimat tersebut menjadi pakaian kita tidak merah sehingga kalimat tersebut tidak berterima. Kalimat tersebut bisa berterima apabila ditambahkan verba berwarna sebelum kata merah. Jadi kalimat tersebut akan menjadi pakaian kita berwarna merah. Selain kalimat statif, berikut adalah contoh kalimat berpola S-P yang tidak berterima.

${ }^{3}$ Minggu satu lagi Jumat.(t3/a/L4)

Kutipan kalimat di atas memiliki satu klausa yang terdiri dari fungsi S dan P. Namun kalimat tersebut tidak berterima, hal ini disebabkan penempatan frasa yang menduduki fungsi $\mathrm{S}$ terbalik. Kalimat tersebut terdiri dari dua frasa, yakni FN + FN. FN pertama terdiri dari N + Num + Adv $\left\{\right.$ minggu $_{n m n h r}+$ satu $_{\text {num }}+$ lagiadv , sedangkan FN kedua adalah $\mathrm{N}_{\text {hari }}$ yakni kata Jumat. Kalimat tersebut merupakan kalimat ekuatif karena selain berpredikat nomina, kalimat tersebut dapat diselipi kata adalah yang akan berfungsi sebagai predikat. Namun, kalimat tersebut tidak berterima karena frasa yang menduduki fungsi S yakni kata minggu satu lagi merupakan susunan yang terbalik. Frasa tersebut akan tepat apabila ditulis satu Minggu lagi sehingga terbentuk kalimat satu Minggu lagi Jumat atau satu Minggu lagi adalah hari Jumat.

Berdasarkan ketiga contoh di atas dapat diketahui bahwa pemelajar tingkat pemula masih terpengaruh tata bahasa bahasa ibu mereka, yakni bahasa Cina. Pemelajar menempatkan nomina sebagai predikat. Hal ini dapat terjadi karena dalam konsep tata bahasa Cina, predikat tidak harus verba, melainkan bisa nomina dan adjektif. Selain itu, tata bahasa sintaktis bahasa Cina menerapkan topik-komen. Hal ini sesuai dengan pendapat yang dikemukakan oleh Yang (2010:54) bahwa dalam bahasa mandarin tidak ada perubahan tens sehingga struktur katanya hampir korespondensi dengan struktur semantis sintaktis "topikkomen". Oleh sebab itu, banyak pemelajar yang menulis dengan pola topik-komen walaupun secara tata bahasa Indonesia masih belum tepat.

Kedua, kalimat berpola fungsi sintaktis $\quad \boldsymbol{S}-\boldsymbol{P}-\boldsymbol{O}$. Kalimat berpola sintaktis S-P-O yang ditemukan merupakan kalimat yang terdiri dari satu klausa, di dalam klausa tersebut terdapat frasa yang menduduki struktur fungsi subjek, predikat, dan objek. Kalimat yang berstruktur S-P-O merupakan kalimat yang berpredikat verba transitif. Verba transitif adalah verba yang wajib diikuti oleh objek. Samsuri menyebut verba ini sebagai verba ekatransitif. Samsuri (1982:348) menyatakan bahwa wujud verba pada kalimat ekatransitif dapat ditandai dengan penggunaan prefiks meN-, sufiks, dan ada yang mengandung prefiks $\{\mathrm{meN}-\}+\{$ per\} atau $\{\mathrm{meN}-\}+\{$ ber- $\}$. Berikut adalah kutipannya.

${ }^{4}$ Merah mewakili kekayaan.(t2/b/M4)

Kutipan kalimat di atas memiliki satu klausa yang berstruktur S-P-O. Di dalam klausa tersebut terdapat tiga frasa, yakni FA + FV + FN ( merah $_{\text {adjkwr }}+$ mewakili $_{\text {vrb }}+$ kekayaan $\left._{n m n}\right)$ yang menduduki struktur fungsi sintaktis. Tiap frasa diisi oleh satu kata. Kata yang menduduki struktur fungsi $\mathrm{S}$ adalah kata merah yang merupakan adjektiva ${ }_{\text {warna. }}$ Kata yang menduduki struktur fungsi $\mathrm{P}$ adalah kata mewakili. Kata ini merupakan verba yang terbentuk dari afiks $\{\mathrm{meN}-\mathrm{i}\}+$ nomina dasar wakil sehingga membentuk verba. Sumadi (2010:84) 
menjelaskan bahwa afiks meN-i memiliki fungsi untuk membentuk verba. Kata ini dikategorikan sebagai verba transitif sehingga memerlukan objek. Jadi pemelajar menempatkan nomina kekayaan untuk menduduki fungsi $\mathrm{O}$ di dalam kalimat tersebut. Secara struktur, kalimat ini berterima karena predikat verba transitif sudah diikuti oleh nomina. Namun, dilihat secara fitur semantis, kalimat ini tidak berterima. Hal ini disebabkan penggunaan verba mewakili. Verba ini terbentuk dari $\{\mathrm{meN}-\}+\mathrm{Nd}$ (nomina dasar) $+\{-\mathrm{i}\}$ yang bermakna 'bertindak sebagai wakil/menyuruh'. Jadi secara harfiah kalimat tersebut bermakna 'merah bertindak sebagai wakil kekayaan' sehingga tidak berterima. Secara semantis, subjek yang dapat menjadi wakil adalah nomina hidup atau manusia dan objek yang diwakili juga merupakan nomina hidup. Kalimat ini akan berterima apabila verba yang menduduki fungsi $\mathrm{P}$ diganti. Verba mewakili dapat diganti dengan penggunaan verba intransitif berarti, sehingga kalimatnya tertulis merah berarti kekayaan yang bermakna 'warna merah menyimbolkan kekayaan'.

Ketiga, kalimat berpola fungsi sintaktis S-P-Pel. Kalimat berpola sintaktis S-P-Pel merupakan kalimat yang terdiri dari satu klausa dan klausa tersebut terdiri dari tiga frasa yang menduduki fungsi subjek, predikat, dan pelengkap. Berikut adalah paparan dan pembahasannya.

${ }^{5}$ Buna adalah kuning.(t2/c/L4)

Kutipan kalimat di atas terdiri dari satu klausa yang menduduki struktur fungsi S-PPel Kalimat tersebut terbentuk dari tiga frasa yakni FN + FV + FA $\left(\right.$ Bunga $_{n m n}+$ adalah $_{\text {vrb }}+$ kuning $_{\text {adjkwr }}$ ). Hal ini dapat diketahui setelah pengajar bertanya pada pemelajar apa yang disebut dengan buna, rupanya kata ini mengacu pada kata bunga. Pemelajar menulis kata bunga karena masih terpengaruh dengan bahasa ibu pemelajar yang tidak mengenal fonem

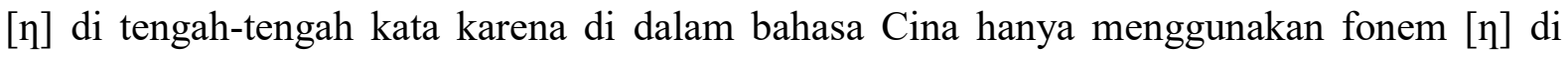
akhir kata, seperti qiáng, āng, dèng, ataupun máng. Kata bunga yang dimaksud merupakan nominatumbuhan yang menduduki struktur fungsi $\mathrm{S}$, kata adalah merupakan kopula yang menduduki struktur fungsi $\mathrm{P}$, dan kata kuning yang merupakan adjektiva ${ }_{\text {warna }}$ menduduki struktur fungsi Pel. Hal ini sudah sesuai dengan teori yang dikemukakan oleh Sumadi (2009:68) bahwa pelengkap adalah bagian kalimat yang mengikuti P yang berupa verba intransitif. Biasanya pelengkap berupa FN, FV, FA, Fnu, atau Fprep. Secara struktur, tampak bahwa kalimat tersebut berterima, tetapi secara makna kalimat ini tidak berterima karena verba adalah diikuti oleh nomina yang mengacu pada S. Kalimat tersebut akan benar apabila penggunaan kopula adalah diganti dengan verba intransitif berwarna sehingga kalimat tersebut akan menjadi bunga berwarna kuning. Berikut adalah contoh kalimat berpola S-PPel yang berterima.

${ }^{6}$ Hari ini adalah Kamis.(t3/c/A1)

Kutipan kalimat di atas merupakan kalimat yang terdiri dari fungsi subjek, predikat, dan pelengkap. Kalimat tersebut terbentuk dari FN + FV + FN. Pada frasa pertama terdiri dari $\mathrm{N}+$ Pron, yakni kata hari dan ini. Fungsi S diisi oleh nomina hari dan pronomina penunjuk ini. Kata ini dikategorikan sebagai pronomina penunjuk umum. Alwi, dkk (2010:267) menyatakan bahwa pronomina ini merupakan pronomina yang mengacu pada acuan yang dekat dengan pembicara atau penulis, pada masa yang akan datang, atau pada informasi yang 
akan disampaikan. Sementara itu, pada fungsi P diisi oleh verba adalah, dan struktur fungsi Pel diisi oleh nomina Kamis. Menurut Alwi, dkk (2010:359), jika kalimat dengan predikat nominal diselipi adalah, maka verba itu berfungsi sebagai predikat, sedangkan nomina atau frasa nominal yang mengikutinya menjadi pelengkap. Secara struktur maupun makna, kalimat ini sudah berterima.

Keempat, kalimat berpola fungsi sintaktis S-P-Ket. Kalimat berpola sintaktis S-PKet merupakan kalimat yang terdiri dari satu klausa. Klausa tersebut memiliki frasa yang menduduki fungsi subjek, predikat, dan keterangan. Ada dua kategori keterangan yang ditemukan, yakni keterangan tempat (Kettp) dan keterangan waktu (Ket $\left.{ }_{\mathrm{wt}}\right)$. Berikut adalah paparan dan pembahasannya.

${ }^{7}$ Saya tinggal di Villa Puncak Tidar M20.(t1/d/V5)

Kutipan kalimat di atas merupakan contoh kalimat yang berstruktur fungsi S-P-Ket. Kalimat tersebut terdiri dari satu klausa yang terdiri dari 3 frasa, yakni FPron + FV + FN. Frasa pertama menduduki fungsi $\mathrm{S}$ yakni pronomina saya. Pronomina saya merupakan pronomina yang dikategorikan dalam pronomina persona pertama tunggal. Menurut Alwi, dkk. (2010:258) saya adalah bentuk yang formal dan umumnya dipakai dalam tulisan atau ujaran yang resmi. Frasa kedua menduduki fungsi $\mathrm{P}$ yakni verba intransitif tinggal. Verba intransitif atau yang bisa disebut dengan verba taktransitif adalah verba yang tidak memiliki nomina di belakangnya yang dapat berfungsi sebagai subjek dalam kalimat pasif (Alwi, dkk. (2010:97)). Namun di dalam kalimat tersebut tidak dapat ditemukan nomina yang dapat diganti menduduki fungsi $\mathrm{S}$ dalam kalimat pasif, sehingga dapat dinyatakan bahwa verba tinggal merupakan verba taktransitif yang tak berpelengkap sehingga diikuti oleh FN yang menduduki fungsi Keterangan. FN yang menduduki fungsi keterangan terdiri dari

Prep $+\mathrm{N}_{\mathrm{tp}}+\mathrm{N}_{\mathrm{tp}}+\mathrm{N}_{\mathrm{tp}}$ tetapi dikategorikan sebagai FN karena yang menjadi konstituen induk adalah villa dan yang menjadi konstituen bawahan adalah preposisi $d i$. FN menduduki fungsi keterangan tempat karena menggunakan preposisi yang menjelaskan tempat, yakni preposisi $\boldsymbol{d i}$.

${ }^{8}$ Saya pergi di toko.(t1/d/A4)

${ }^{9}$ Saya akan pergi ke kafe hari Jumat.(t3/d/M5)

${ }^{10}$ Saya pergi ke Batu pada hari Minggu.(t3/d/V1)

Ketiga kutipan kalimat di atas merupakan kalimat yang berstruktur fungsi subjek, predikat, dan keterangan. Ketiga kalimat tersebut terdiri dati satu klausa, masing-masing klausa terdiri dari 3 frasa, yakni FPrn+FV+FN. Pada ketiga kalimat tersebut dapat diketahui bahwa ada tiga pemelajar yang menggunakan kata yang sama untuk menduduki struktur fungsi S dan P. Kata yang menduduki struktur fungsi S adalah pronomina saya dan kata yang menduduki struktur $\mathrm{P}$ adalah verba pergi. Walaupun pada kalimat kedua tampak bahwa pemelajar menggunakan kata akan sebelum verba. Kata akan merupakan adverbia. Menurut Sumadi (2009:158), adverbia adalah kategori yang dapat mendampingi adjektiva, numeralia, atau preposisi dalam konstruksi sintaksis. Adverbia ini berpengaruh terhadap makna dalam kalimat, sehingga jika dilihat berdasarkan maknanya dapat diketahui bahwa subjek pada kalimat pertama sudah pergi, tetapi subjek pada kalimat kedua masih belum pergi (masih 
berencana pergi). Jika dilihat secara struktur, ketiga kalimat tersebut berterima. Namun, ada penggunaan preposisi yang tidak tepat pada kata klausa yang menduduki struktur fungsi Ket, yakni kalimat pertama. Pada kalimat pertama tersebut ditulis Saya pergi di toko. Verba pergi tidak dapat diikuti oleh preposisi di, sehingga preposisi yang tepat adalah preposisi dari/ke. Sementara itu pada kalimat kedua dan ketiga sudah berterima. Pada kalimat kedua terdiri dari dua jenis keterangan, yakni keterangan tempat dam keterangan waktu. Klausa yang menduduki fungsi keterangan tempat adalah ke kafe dan klausa yang menduduki struktur fungsi keterangan waktu adalah hari Jumat. Pada kalimat ketiga tampak juga ada dua jenis keterangan, yakni keterangan tempat dan keterangan waktu. Keterangan tempat ditandai dengan penggunaan preposisi $\boldsymbol{k} \boldsymbol{e}$ dan keterangan waktu yang ditandai dengan penggunaan preposisi pada. Frasa yang menduduki fungsi sintaktis keterangan tempat adalah ke Batu dan frasa yang menduduki fungsi sintaktis keterangan waktu adalah pada hari Minggu.

Kelima, kalimat berpola fungsi sintaktis $\boldsymbol{S}$-P-O-Ket. Kalimat berpola sintaktis S-PO-Ket merupakan kalimat yang terdiri dari satu klausa yang memiliki empat frasa. Masingmasing frasanya menduduki fungsi subjek, predikat, objek, dan keterangan. Pada pola fungsi sintaktis ini hanya ditemukan penggunaan keterangan waktu (Ket $\left.{ }_{\mathrm{wt}}\right)$ dan hanya ditulis oleh satu pemelajar saja. Berikut adalah paparan dan pembahasannya.

${ }^{11}$ Kami memiliki kelas bahasa Indonesia pada hari Senin.(t3/e/M1)

Pada kutipan di atas terdapat satu klausa yang terdiri dari empat frasa. Masing-masing frasa tersebut menduduki struktur fungsi subjek, predikat, objek, dan keterangan. Fungsi S diduduki oleh pronomina kami. Pronomina kami adalah pronomina persona jamak yang ekslusif. Artinya pronomina itu mencakupi pembicara atau penulis dan orang lain di pihaknya, tetapi tidak mencakupi orang lain di pihak pendengar atau pembacanya (Alwi, dkk. 2010:259). Sementara itu, fungsi P diduduki oleh verba memiliki. Verba ini menggunakan prefiks $\{$ meN- $\}$ dan sufiks $\{-i\}$ pada nomina dasar milik yang bermakna 'membuat jadi milik. Hal ini sesuai dengan teori Sumadi (2010:85) yang mengemukakan bahwa afiks meN-i mempunyai makna 'membuat jadi yang tersebut pada bentuk dasar. Afiks ini membuat kata milik menjadi verba, yakni verba transitif yang memerlukan hadirnya $\mathrm{O}$. O dapat diisi oleh nomina. Sumadi (2009:49) menjelaskan bahwa ciri O adalah berkategori nomina, berada langsung di belakang verba transitif aktif tanpa preposisi, dapat menjadi subjek dalam kalimat pasif, dan dapat diganti -nya. Oleh sebab itu, kata yang menduduki fungsi $\mathrm{O}$ adalah kelas bahasa Indonesia. Setelah menempatkan O, penulis juga menempatkan keterangan waktu. Hal ini ditandai dengan penggunaan preposisi pada. Jadi FN yang menduduki fungsi Ket $_{\text {waktu }}$ adalah pada hari Senin. Frasa pada hari Senin ini disebut sebagai periferal karena proposisi dalam kalimat tersebut adalah saya memiliki kelas bahasa Indonesia. Selain contoh kutipan tersebut, tidak ada pemelajar lain yang menulis kalimat berstruktur lengkap S-P-OKet. Hal in dapat terjadi karena materi berkaitan dengan verba aktif $\{\mathrm{meN}-\}$ belum diberikan pada pemelajar.

Berdasarkan kutipan 7 hingga 11 tampak bahwa pemelajar lebih dominan menggunakan pronomina persona pertama atau pronomina persona kedua untuk fungsi sintaktis S. Bahkan, berdasarkan keseluruhan data tidak ada pemelajar yang menggunakan pronomina persona ketiga tunggal ataupun jamak, walaupun materi tentang kata ganti sudah diajarkan pada mereka. Hal ini membuktikan bahwa tidak semua materi yang disampaikan 
dapat disimpan dalam memori jangka panjang pemelajar. Ada materi yang mudah dipahami oleh pemelajar dan ada yang sulit dipahami oleh pemelajar. Salsburry, Crossley, dan McNamara (2011:345) juga menyatakan bahwa untuk mengukur kata-kata yang sulit diperoleh oleh pemelajar dapat diketahui berdasarkan frekuensi kemunculan kata dalam kalimat atau teks yang ditulis. Hal ini membuktikan teori yang dikemukakan oleh Ellis (2003:22) pula bahwa kesulitan struktur yang dialami oleh pemelajar ialah saat mempelajari materi kalimat pasif dan kata ganti orang ketiga.

Selain itu, adanya interferensi bahasa ibu juga memengaruhi kalimat yang diproduksi oleh penutur bahasa kedua, khususnya ketiga konsep pada bahasa kedua berbeda dengan konsep pada bahasa pertama. Misalnya pada materi kata ganti orang ketiga. Dalam bahasa Indonesia, kata ganti orang ketiga jamak mereka dapat mengacu pada orang laki-laki ataupun perempuan ataupun laki-laki dan perempuan. Alwi, dkk. (2010:265) menyatakan bahwa mereka tidak mempunyai variasi bentuk sehingga dalam posisi manapun hanya bentuk itulah yang dipakai. Namun, di dalam bahasa Cina kata ganti dia atau mereka harus dibedakan dalam penulisan aksaranya (hanzi). Chaofen (2006:166) menjelaskan bahwa konsep kata ganti orang ketiga di dalam bahasa Cina dipilah menjadi tiga, yakni orang ketiga laki-laki semua (他們/他们), orang ketiga perempuan semua (她們/她们), dan orang ketiga yang bukan manusia (termasuk benda mati) (它們/它们). Selain itu Chaofen juga menegaskan bahwa penutur Cina lebih memilih untuk mengulang nama dibandingkan menggunakan kata ganti orang ketiga.

\section{Kalimat Tidak Berklausa}

Kalimat tidak berklausa adalah kalimat yang terdiri atas satuan gramatik yang bukan merupakan klausa. Pada kalimat ini tidak dapat ditemukan fungsi-fungsi suntaktis tertentu. Pada penelitian ini hanya dapat ditemukan satu jenis data yang merupakan kalimat tidak berklausa. Berikut adalah paparannya.

${ }^{12}$ Selamat pagi.(t1/f/A3)

Kutipan kalimat di atas merupakan kalimat yang tidak berklausa. Di dalam kalimat tersebut hanya terdiri dari dua kata, yakni selamat dan pagi. Kedua kata ini tidak dapat diklasifikasikan dalam fungsi-fungsi sintaktis. Sumadi (2009:164) menjelaskan bahwa kalimat tidak berklausa ialah kalimat yang terdiri atas satuan gramatik yang bukan merupakan klausa. Selain kalimat tersebut, tidak ditemukan kalimat tidak berklausa yang lain.

\section{SIMPULAN}

Penelitian ini memiliki satu simpulan sesuai dengan fokus penelitian, yakni pola kalimat bahasa Indonesia pemelajar BIPA tingkat pemula asal Tiongkok. Berdasarkan hasil analisis dapat dinyatakan bahwa pemelajar sudah dapat menulis kalimat sederhana bahasa Indonesia dengan kosakata bahasa Indonesia yang sudah mereka peroleh selama proses pembelajaran. Kalimat-kalimat yang mereka produksi berhubungan dengan materi dan latar belakang bahasa pertama mereka. Kalimat tersebut dapat dipilah menjadi dua, yakni kalimat berklausa dan kalimat tidak berklausa. Pada kalimat berklausa, pemelajar dapat menulis kalimat yang terdiri dari fungsi sintaktis S-P, S-P-O, S-P-Pel, S-P-Ket, dan S-P-O-Ket. Kalimat dengan fungsi sintaktis S-P merupakan kalimat yang paling dominan ditulis oleh 
pemelajar. Kalimat S-P tersebut dapat dikategorikan menjadi dua, yakni kalimat ekuatif dan kalimat statif. Sementara itu, pada kalimat tidak berklausa hanya ditemukan satu bentuk saja, yakni kalimat tidak berklausa yang terdiri atas dua kata.

\section{DAFTAR RUJUKAN}

Alwi, H., Dardjowidjojo, S., Lapoliwa, H., dan Moelino, A.M. 2010. Tata Bahasa Baku Bahasa Indonesia. Jakarta: Balai Pustaka.

Chaofen, S. 2006. Chinese: A Linguistic Introduction. Cambridge: Cambridge Press.

Ellis, R. 2003. Second Language Acquisition. Oxford: Oxford University Press.

Langacker, R.W. 1973. Language and Its Structure: Some Fundamental Linguistic Concepts. San Diego: Harcourt Brace Jovanovich Publishers.

Muliastuti, L. 2017. Bahasa Indonesia bagi Penutur Asing: Acuan Teori dan Pendekatan Pengajaran. Jakarta: Yayasan Pustaka Obor Indonesia.

Samsuri. 1985. Tata Kalimat Bahasa Indoensia. Jakarta: Sastra Hudaya.

Salsburry T., Crossley, S.A., dan McNamara, D.S. 2011. Psycholinguistic Word Information in Second Language Oral Discourse. Second Language Research, 27 (3). (Online), (http://slr.sagepub.html), diakses 02 Juli 2018.

Saville, M. dan Troike. 2006. Introducing Second Language Acquisition. Cambridge:

Cambridge University Press.

Sumadi. 2009. Sintaksis Bahasa Indonesia. Malang: UM Press.

Sumadi. 2010. Morfologi Bahasa Indonesia. Malang: UM Press.

Suyitno, I. 2004. Pengetahuan Dasar BIPA: Pandangan Teoritis Belajar Bahasa.

Yogyakarta: Grafika Indah.

Tadjudin,M., Djajasudarma, T. F., dan Wahya. 1999. Pemerolehan Bahasa Asing: Anak Bilingual Sunda-Indonesia di Kotamadya Bandung. Jakarta: Pusat Pembinaan dan

Pengembangan Bahasa Departemen Pendidikan dan Kebudayaan.

Verhaar, J.W.M. 2010. Asas-Asas Linguistik Umum. Yogyakarta: Gadjah Mada University Press.

Yang, Y. 2010. Predikat dalam Bahasa Indonesia dan Bahasa Mandarin. Skripsi tidak diterbitkan. Surakarta: Pascasarjana Universitas Sebelas Maret. 